\title{
PREVALENCE AND TRANSMISSION OF INTESTINAL PARASITOSIS IN HUMAN BEINGS FROM ZONA DA MATA, MINAS GERAIS, BRAZIL
}

\author{
PREVALÊNCIA E TRANSMISSÃO DE PARASITOSES INTESTINAIS EM SERES \\ HUMANOS NA ZONA DA MATA DE MINAS GERAIS
}

\author{
Adriana Felix IASBIK ${ }^{1}$; Paulo Sérgio de Arruda PINTO ${ }^{2 *}$; \\ Rafaella Paola Meneguete GUIMARÃES-PEIXOTO ${ }^{2}$; Tatiane de Oliveira SANTOS ${ }^{2}$; \\ Fernanda Mara FERNANDES ${ }^{3}$; Letícia Ferreira da SILVA ${ }^{2}$; André Ricardo e SILVA ${ }^{4}$; \\ Sebastião Ezequiel VIEIRA ${ }^{3}$; Jackson Victor ARAÚJO ${ }^{4}$ \\ 1. Agricultural Institute of Minas Gerais - IMA, Minas Gerais, Brazil; 2. Laboratory of Animal Products Inspection, Department of \\ Veterinary Medicine, Federal University of Viçosa (UFV), Minas Gerais, Brazil, pintopsa@ufv.br ; 3. Laboratory of Parasitology, \\ Faminas, Muriaé, Minas Gerais, Brazil; 4. Laboratory of Parasitology Veterinary, Department of Veterinary Medicine, Federal \\ University of Viçosa (UFV), Minas Gerais, Brazil.
}

\begin{abstract}
Intestinal parasites are closely related to basic sanitary conditions, socioeconomic status, level of education, age and hygiene habits of the population; it is a serious Brazilian public health problem. This study aims to identify the prevalence of intestinal parasites in two municipalities of Zona da Mata, State of Minas Gerais, Brazil. We analyzed the samples using spontaneous sedimentation technique. In Viçosa, collecting data from hygienic and sanitary characteristics was possible by applying a structured questionnaire. The diagnosis revealed $11.2 \%$ intestinal parasites in urban areas and $27.7 \%$ in rural areas. In Muriaé, the prevalence of intestinal parasites was $13.85 \%$ in urban areas. The majority of parasites found in Viçosa were Ascaris lumbricoides, Ancylostoma duodenale, Entamoeba coli and E. histolytica. Furthermore, in Muriaé we found Strongyloides stercoralis, Ascaris lumbricoides, Ancylostoma sp, Taenia sp, Hymenolepis nana, Enterobius vermicularis, Giardia lamblia, Endolimax nana, Entamoeba coli and E. histolytica. These parasites may indicate principally instability in the socio-economic conditions, serving as an important warning for local public health. In both areas, enteroparasitosis is high and it is of great importance to initiate sanitary measures to reduce them.
\end{abstract}

KEYWORDS: Prevalence. Enteroparasitosis. Risk factors. Zona da Mata-Minas Gerais.

\section{INTRODUCTION}

Worldwide, parasites, protozoa and pathogenic helminthes affect around more than two million people (MORRONE et al., 2004). In developing countries, intestinal parasites are responsible for high morbidity, which is an important determinant of infant morbidity and mortality (OLIVEIRA, 2004). In Brazil, intestinal parasites are still a serious problem for the public health, causing significant morbidity and mortality, which is an important health and social problem, mainly in low socioeconomic level of the population (BARRETO, 2006).

Ascariasis, trichuriasis, hookworm infections and some intestinal nematodiasis are among the neglected tropical diseases of high importance and impacts on public health, but are not restricted to tropical and subtropical regions (ANDRADE et al., 2010). Parasites can cause several injuries to the hosts, such as intestinal obstruction (Ascaris lumbricoides), malnutrition (A. lumbricoides and Trichuris trichiura) iron deficiency anemia (hookworm), abdominal pain, nausea and weight loss (Taenia sp.), diarrhea and poor absorption (Entamoeba histolytica, Isospora belli and Giardia lamblia). Clinical manifestations are dependent on the type of parasite and health status of the patient (FERREIRA et al., 2000; LINDSAY et al., 2007; PFUETZENREITER; PIRES et al., 2000).

An epidemiological survey carried out in Brazil showed that $55.3 \%$ of the sampled children were parasitized, and $51 \%$ of them had polyparasitism (ROCHA et al,. 2000). Although intestinal parasites are relevant in epidemiology and public health, it was difficult to perform fecal examinations on a larger scale, which could contribute to clarify the consequences in general population (ANDRADE et al,. 2010).

The variation in frequency of intestinal parasites is closely related to the area of study, sanitation conditions, socioeconomic status, level of education, age, individual hygiene habits and even direct contact (person to person), especially in daycare centers, nursing homes, orphanages and clinics (GURGEL et al., 2005).

Ferreira et al., (2006) performed a study with children in municipal daycare centers in Guarapuava (PR) and related risk factors for 
intestinal parasites, linking close relation between precarious life conditions, intestinal parasitosis and inappropriate development. Parasites are highly found in places where the living conditions and sanitation are unsatisfactory or nonexistent (ANDRADE et al., 2010). According to the Brazilian Institute of Geography and Statistics (IBGE, 2004), the percentage of population served by potable water supply is smaller in rural area compared to the urban area in all Brazilian regions, with a difference of $91.9 \%$ to $25.2 \%$, respectively.

The high prevalence of parasitic diseases in Brazil is due to the difficult access to basic sanitation and lack of health education programs for the poor population, resulting in high morbidity and often linking up the cases of chronic diarrhea and malnutrition, compromising the physical and intellectual of the population (MELO, 2010).

This study aimed to determine the prevalence and risk factors of intestinal parasites transmission in the rural and urban areas in Zona da Mata, Minas Gerais, Brazil.

\section{MATERIAL AND METHODS}

\section{Samples collected in Viçosa}

Stool samples from 419 individuals were collected in 2008 and 2009. The residents were from Viçosa (MG), Brazil, in the Zona da Mata region. From all samples, 90 were from children from the urban area belonging to seven municipal day care centers; 63 samples were from children up to 10 years old from three neighborhoods of the city outskirts; and 266 samples were from children and adults in the countryside of Viçosa. Only children living in urban areas were assisted by the Family Health Program (FHP).

All samples were collected individually. From the total of sampled individuals, we collected data from 329 cases on the hygienic and sanitary characteristics through a questionnaire in which knowledge was taken as the hygiene habits and living conditions. The samples were collected in plastic container with preservative MIF solution (Mercury, Iodine and Formaldehyde). For fecal diagnosis, it was used spontaneous sedimentation method HPJ (Hoffman method, Pons \& Janer) (ARAÚJO, 2006). The Chi square test $(\chi 2)$ compared the groups, at 5\% significance level of $(\mathrm{p}<0.05)$.

\section{Samples collected in Muriaé}

Samples were conducted from May 2007 to February 2015, with patients treated in the hospital located in Muriaé. This Hospital receives patients from all municipalities of the Zona da Mata region. The information was obtained through Oracle Database 10G version, with SQL Bank Manipulation Tool Tools 1.6. All parasitological stool tests performed at the hospital during the period have been included, totalizing 1.832 samples. In Muriaé, applying the epidemiological questionnaire was not possible.

The sample identification procedures were performed in the Clinical Analysis Laboratory of the Hospital using spontaneous sedimentation techniques (HPJ). The samples were collected in plastic container with preservative MIF solution. Patients were considered positive after confirmation of any enteroparasite (helminths or protozoa).

\section{RESULTS}

The parasitological diagnosis revealed 39\% (163 individuals) intestinal parasites in Viçosa, $11.2 \%$ from urban areas and $27.7 \%$ from rural zone. There was no statistically significant difference between the prevalence of urban and rural areas, as shown in Table 1. The most prevalent parasitic diseases in Viçosa were Entamoeba coli, Ascaris lumbricoides, Entamoeba histolytica and Ancylostoma duodenale respectively shown in Table 2.

Table 1. Comparison of intestinal parasites cases diagnosed in individuals living in urban and rural areas in Viçosa, Minas Gerais, Brazil, from 2008 to 2009.

\begin{tabular}{lcccc}
\hline \multirow{2}{*}{ Cases of intestinal parasites } & \multicolumn{3}{c}{ Present } & \multicolumn{2}{c}{ Absent } \\
\cline { 2 - 5 } & $\mathrm{N}$ & $\%$ & $\mathrm{~N}$ & $\%$ \\
\hline Urban area & 47 & 11.2 & 372 & 88.8 \\
Rural zone & 116 & 27.7 & 303 & 72.3 \\
\hline
\end{tabular}

There were differences $(\mathrm{p}<0.01)$ between treatments using the chi-square test $(\chi 2)$ with Yates correction. 
Ascaris lumbricoides was the major helminth found, 6.92\%. Ancylostoma duodenale appeared in $3.57 \%$ and Strongyloides stercoralis was the third highest prevalence of helminths, $1.91 \%$. Regarding the population interviewed in the city, $3.64 \%$ said they have open sewers, which is considered an important risk factor for the persistence of this helminth.

Considering intestinal protozoan, Entamoeba histolytica and E. coli were the most prevalent (11.45\% and 5.25\%, respectively). Giardia duodenalis and Giardia lamblia also appeared in this study, both with $1.91 \%$; the World Health Organization considers them as zoonoses. The prevalence for genus Isospora was $0.94 \%$. We observed that $95.7 \%$ of the study population had the habit of consuming fruits and vegetables without appropriate washing.

Table 2. Prevalence (\%) of intestinal parasites found in fecal examinations of individuals living in Viçosa municipality, from 2008 to 2009.

\begin{tabular}{lcc}
\hline Enteroparasites & Positive & Prevalence ( \%) \\
\hline Helminth & 29 & 6.92 \\
Ascaris lumbricoides & 15 & 3.57 \\
Ancylostoma duodenale & 08 & 1.91 \\
Strongyloides stercoralis & 05 & 1.19 \\
Trichuris trichiura & 04 & 0.95 \\
Enterobius vermicularis & 01 & 0.23 \\
Hymenolepis diminuta & 01 & 0.23 \\
Taenia sp. & 64 & 15.23 \\
\hline Total & & \\
\hline Protozoa & 48 & 11.45 \\
Entamoeba coli & 22 & 5.25 \\
Entamoeba histolytica & 08 & 1.91 \\
Giardia duodenalis & 08 & 1.91 \\
Giardia lamblia & 04 & 0.94 \\
Isospora belli & 90 & 21.46 \\
\hline Total & & \\
\hline
\end{tabular}

Considering cestoidea, only one case of Hymenolepis diminuta occurred and another one of Taenia sp., representing both $0.23 \%$ of the total occurrence. Despite the low prevalence of taeniasis in the population, open sewage favors the transmission and maintenance of this zoonosis. Characteristics such as low socioeconomic status, non-treated water consumption, open sewages, consumption of fruits and vegetables without appropriate washing were observed in this study.

In relation to households surveyed, $95.1 \%$ had pets and only $8.8 \%$ of people were assisted by the FHP. Regarding the monthly income in the urban zone, $59.1 \%$ of individuals who tested positive for some intestinal parasites had incomes from $\mathrm{R} \$ 301.00$ to $\mathrm{R} \$ 500.00$. There was a significant difference $(\mathrm{p}<0.05)$ of income distribution and cases of intestinal parasites.

For age analysis, there was higher prevalence of intestinal parasites in the 0-6 years old children group (45\%), showing a significant difference $(\mathrm{p}<0.05)$ compared with the 7-10 years old children group. In the rural zone, 1-4 years old children group had the highest prevalence $(66.7 \%)$ of intestinal parasitism, which is probably due to lack of personal hygiene habits. Regarding positive results by age group in the rural zone, there was a decline of these values as the age group increases, confirming the downward trend for intestinal parasites as the age group increases.

The distribution of intestinal parasites prevalence according to age and gender was variable. There was no statistical significant difference $\quad(p>0.05)$. By comparing the epidemiologically responsible variables for the maintenance and transmission of intestinal parasites (Table 3), a statistically significant difference occurred for the variables clean water, open sewages, network sewage, domestic animals, consumption of fruits and vegetables without appropriate washing, consumption of uncooked meat and routine feces parasitology test. 
Table 3. Distribution of hygiene and sanitary characteristics and risk factors for the population in urban and rural areas in Viçosa from 2008 to 2009.

\begin{tabular}{|c|c|c|c|c|c|c|}
\hline \multirow{2}{*}{$\begin{array}{l}\text { Hygienic and } \\
\text { sanitary } \\
\text { characteristics }\end{array}$} & \multirow{2}{*}{$\begin{array}{c}\text { Comments } \\
\text { (N) }\end{array}$} & \multirow{2}{*}{$\begin{array}{c}\text { Total } \\
\text { frequency }\end{array}$} & \multicolumn{2}{|c|}{ Frequency in urban area } & \multicolumn{2}{|c|}{ Frequency in rural zone } \\
\hline & & & $\mathbf{N}^{\mathbf{o}}$ & $\%$ & $\mathbf{N}^{\mathbf{o}}$ & $\%$ \\
\hline \multirow{2}{*}{$\begin{array}{l}\text { Potable water }^{(a)} \\
\text { Open sewer }^{(a)}\end{array}$} & 329 & 62 & 53 & 85.5 & 19 & 14.5 \\
\hline & 329 & 12 & 10 & 83.3 & 02 & 16.7 \\
\hline $\begin{array}{c}\text { Rare meat } \\
\text { consumption }\end{array}$ & 329 & 131 & 08 & 6.1 & 123 & 93.9 \\
\hline Sewage system ${ }^{\text {(a) }}$ & 329 & 286 & 46 & 16.0 & 240 & 84.0 \\
\hline Domestic animals & 329 & 313 & 47 & 15.0 & 266 & 85.0 \\
\hline $\begin{array}{l}\text { Consumption of } \\
\text { fruits and vegetables } \\
\text { without appropriate } \\
\text { washing }^{(a)}\end{array}$ & 329 & 315 & 49 & 15.5 & 266 & 84.5 \\
\hline $\begin{array}{l}\text { Health Family } \\
\text { Program (HFP) }\end{array}$ & 329 & 29 & 29 & 100.0 & $*$ & - \\
\hline $\begin{array}{c}\text { Routine fecal } \\
\text { examinations }\end{array}$ & 275 & 125 & 07 & 5.6 & 118 & 94.4 \\
\hline $\begin{array}{c}\text { Habit of walking } \\
\text { barefoot }\end{array}$ & 53 & 21 & 21 & 100.0 & $*$ & - \\
\hline $\begin{array}{l}\text { Vacant lot near the } \\
\text { residence }\end{array}$ & 53 & 34 & 34 & 100.0 & $*$ & - \\
\hline $\begin{array}{c}\text { Smoking / Wash } \\
\text { hands }\end{array}$ & 53 & 44 & 44 & 100.0 & $*$ & - \\
\hline
\end{tabular}

* There were not collected data on these variables; (a) variables were statistically significant $\mathrm{p}<0.05$ between urban and rural areas in $\chi^{2}$ test with Yates correction.

In relation to Muriaé, intestinal parasites were found in $13.85 \%$ of the sampled population. The helminths were Strongyloides stercoralis (0.49\%), Ascaris lumbricoides (0.33\%), Ancylostoma sp. (0.27\%), Taenia sp. (0.11\%), Hymenolepis nana (0.11\%), and Enterobius vermicularis $(0.05 \%)$. The protozoan were Giardia lamblia (5.29\%), which was the most prevalent, followed by Endolimax nana (3.49\%), Entamoeba coli $(3.33 \%)$ and Entamoeba histolytica $(0.38 \%)$ (Table 4).

Table 4. Intestinal parasites in patients treated at a hospital in Zona da Mata region (Muriaé-MG), from May 2007 to February 2015.

\begin{tabular}{lcc}
\hline Description & Samples & \% \\
\hline Positive Tests & 254 & $13.85 \%$ \\
Negative Tests & 1578 & $86.15 \%$ \\
Total & 1832 & $100 \%$ \\
Giardia lamblia & 97 & $5.29 \%$
\end{tabular}




\section{Endolimax nana}

Entamoeba coli

Strongyloides stercoralis

Entamoeba histolytica

Ascaris lumbricoides

Ancylostoma sp.

Hymenolepis nana

Taenia sp.

Enterobius vermicularis
64

61

9

7

6

5

2

2

1
$3.49 \%$

$3.33 \%$

$0.49 \%$

$0.38 \%$

$0.33 \%$

$0.27 \%$

$0.11 \%$

$0.11 \%$

$0.05 \%$
The higher prevalence in Muriaé was protozoa, which may indicate a deficiency in the treatment of water used for human consumption, since most of these can resist certain hard treatments. Brazilian law recognized the impact of these agents and recommended by Ordinance 518/2004 the search for Cryptosporidium and Giardia in water used as public supply.

According to the results, the parasite with the highest prevalence was Giardia lamblia with 97 positives (5.29\%). About helminths, Strongyloides stercoralis $(0.49 \%)$ was the most prevalent, followed by Ascaris lumbricoides (0.33\%), Ancylostoma sp. (0.27\%), Taenia sp. (0.11\%), Hymenolepis nana (0.11\%), and Enterobius vermicularis $(0.05 \%)$.

Regarding the gender of patients, 1.172 (64\%) were women, $32 \%$ from the $28-40$ years old group and $68 \%$ from the $40-68$ years old group. Six hundred and sixty patients (36\%) were male, $17 \%$ from the 37-50 years old group and $83 \%$ from the 50-74 years old group. In women, parasites were positive for $8.40 \%$ and $5.45 \%$ in men. In both genders, the age group most affected with some parasitosis was patients from 40-68 years old for women and 50-74 years old for men.

\section{DISCUSSION}

It is important to consider the risk factors involved in the transmission of intestinal parasites and maintenance of their cycles. Campos et al., (2002) found an association between endoparasites and poor socioeconomic and environmental conditions, low family income and low homemaker educational level.

According to Oliveira, Germano (1992), Brazil has often vegetables fertilized and irrigated with water contaminated with human faeces. It increases the risk of population to acquire diseases. Among the most frequently helminths worldwide around $25-30 \%$ of the worldwide population is infected with Ascariasis each year, with at least 10.000 deaths, mostly children, due to complications resulting from infections, as chronicity and intestinal obstruction (SILVA, 2005; SILVA et al., 1997).

Hookworm has broad geographic distribution with high occurrence, constituting one of the most common infections in rural zones. Its transmission relates to the direct contact of the skin or mucous membranes with infected soil, highlighting environmental contamination, which would avoid population diseases (LEITE, 2005) if prevented, as can be verified in this study.

There was high occurrence of protozoan, such as Entamoeba coli $(11.45 \%$ in Viçosa and $3.33 \%$ in Muriaé). It is a commensal species, which rarely causes clinical symptoms, but is an important indicator of the parasitic situation of the analyzed environment. Entamoeba histolytica is the only specie in the genus that in certain cases can be pathogenic for humans (SILVA; GOMES, 2005). An estimation of 500 million individuals are infected by $E$. histolytica in the world, and 50 million of these present the invasive form, leading to 100.000 deaths per year, mostly for colitis and liver abscess (WHO, 1997). However, knowledge about commensal parasites is important as the individual has the parasite transmission cycle, showing the need for actions relating to educational activities (GONÇALVES et al., 2011).

The protozoan Giardia lamblia has high prevalence in developing and underdeveloped countries (WHO, 1997). Its transmission can occurs through water, vegetables, fruits and vegetables 
poorly washed, serving as a vehicle for transmission of cysts (MELO et al., 2004). The high rate of infection caused by this parasite may indicate socioeconomic conditions considering these patients lifestyle, since the protozoa have fecal-oral transmission.

Pets should be considered, because they can act directly or indirectly as a potential disseminator of zoonosis. Despite not having been found positive cryptosporidiosis in both municipalities, a zoonotic disease often affects people living in contact with domestic animals as they serve as disseminators of oocysts of Cryptosporidium spp. to the environment (NAVARRO et al., 1997; FERNANDES et al., 2008).

Water origin must be analyzed, since it can act as a propagation vehicle for the infection of enteroparasitosis (OLIVEIRA, 2004), remembering that meat quality should also be taken into account because it can become a transmission vehicle, including for Taenia saginata and Taenia solium.

All enteroparasites reported in this study stand out, as they are current indicators of the health situation in the analyzed sites. Competent authorities related to public health should work with sanitary measures to reduce the parasitic indexes, since in addition to the safety and welfare of the population, there will be a drop in the amounts spent with hospital treatments, funded by the Brazilian government.

\section{CONCLUSIONS}

The results reveal an epidemiological profile of enteroparasitoses in the Zona da Mata region in the State of Minas Gerais, based on the prevalence rates and risk factors identified in this survey.

Intestinal parasites are present in the environment affecting the human population primarily by ingestion of contaminated food and water.

The high prevalence of intestinal parasites reported in these municipalities is mainly due to scarce access to basic sanitation and the lack of health education programs.

\section{ACKNOWLEDGMENTS}

The authors would like to thank Fapemig (Research Support Foundation of Minas Gerais), CAPES (the Coordination for the Improvement of Higher Education Personnel), and CNPq (National Council of Technological and Scientific Development) for the financial support.

RESUMO: A prevalência de parasitoses intestinais está intimamente relacionada com as condições de saneamento básico, situação socioeconômica, nível de educação, idade e hábitos de higiene da população, e continua sendo um grave problema de saúde pública no Brasil. Este estudo tem como objetivo principal identificar a prevalência dos parasitas intestinais em dois municípios da Zona da Mata do Estado de Minas Gerais, Brasil. As amostras coletadas foram analisadas pela técnica de sedimentação espontânea. No município de Viçosa, foi possível coletar dados de características higiênicas e sanitárias através da aplicação de questionário epidemiológico estruturado, onde foi encontrada uma prevalência de $11,2 \%$ nas áreas urbanas e $27,7 \%$ nas rurais de parasitas intestinais. Em Muriaé, a prevalência de parasitas intestinais foi de 13,85\% nas áreas urbanas. Os principais parasitas encontrados em Viçosa foram: Ascaris lumbricoides, Ancylostoma duodenale, Entamoeba coli e E. histolytica. Em Muriaé foram encontrados Strongyloides stercoralis, Ascaris lumbricoides, Ancylostoma sp, Taenia sp, Hymenolepis nana, Enterobius vermicularis, Giardia lamblia, Endolimax nana, Entamoeba coli e E. histolytica. A presença destes parasitas se associaram à precariedade nas condições socioeconômicas e sanitárias da população, servindo como um importante alerta para a Saúde Pública. Pôde-se observar que, em ambas as cidades, as enteroparasitoses apresentaram altas prevalências, indicando a necessidade de se adotar medidas sanitárias para diminuir essas prevalências.

PALAVRAS-CHAVE: Prevalência. Enteroparasitoses. Fatores de risco. Zona da Mata-Minas Gerais.

\section{REFERENCES}

ANDRADE, E. C.; LEITE, I. C. G.; RODRIGUES, V. O.; CESCA, M. G. Parasitoses intestinais: uma revisão sobre seus aspectos sociais, epidemiológicos, clínicos e terapêuticos. Revista de Atenção Primária à Saúde, Juiz de Fora, v. 13, n. 2, p. 231-240, 2010.

ARAÚJO, J. V. Diagnóstico das helmintoses. Viçosa: Editora Universidade Federal de Viçosa. 2006; 47p. 
BARRETO, J. G. Detecção da incidência de enteroparasitos nas crianças carentes da cidade de Guaçuí - ES. Revista Brasileira de Análises Clínicas, Rio de Janeiro, v. 38, n. 4, p. 221-223, 2006.

BRASIL. Ministério do Planejamento, Orçamento e Gestão. IBGE: Instituto Brasileiro de Geografia e Estatística Resultados da Amostra do Censo Demográfico 2000: Situação em 2001. Rio de Janeiro; 2004.

CAMPOS, M. R.; LUIS, V. I. O.; FORTES, B. P. M. D.; BRAGA, R. C. C.; MEDRONHO, R. A. Distribuição espacial da infecção por Ascaris lumbricoides. Revista de Saúde Pública, São Paulo, v. 36, n. 1, p. 69-74, 2002.

FERNANDES, A. B.; BAÊTA, B. A.; FILHO, W. F. V.; MASSAD, F. V.; REBOUÇAS, F. A.C. F.; CARVALHO, J. B. Relação entre animais de companhia e parasitoses intestinais em crianças, município de Seropédica, RJ. Revista Brasileira de Parasitologia Veterinária, Jaboticabal, v. 17, n. 1, p. 296-300, 2008.

FERREIRA, U. M.; FERREIRA, C. S.; MONTEIRO, C. A . Tendência secular das parasitoses intestinais na infância na cidade de São Paulo (1984-1996). Revista de Saúde Pública, São Paulo, v. 34, n. 6, p. 73-82, 2000. https://doi.org/10.1590/S0034-89102000000700010

FERREIRA, H.; LALA, E. R. P.; MONTEIRO, M. C.; RAIMONDO, M. L. Estudo epidemiológico localizado da frequência e fatores de risco para enteroparasitoses e sua correlação com o estado nutricional de crianças em idade pré-escolar Parasitoses intestinais e desenvolvimento infantil. Publicatio Universidade Estadual de Ponta Grossa: Ciências Biológicas e da Saúde, Ponta Grossa, v. 12, n. 4, p. 33-40, 2006.

GONÇAlVES, A. L. R.; BEllZÁRIO, T. L.; PIMENTEL, J. B.; PENATTI, M. P. A.; PEDROSO, R. S. Prevalence of intestinal parasites in preschool children in the region of Uberlândia, State of Minas Gerais, Brazil. Revista da Sociedade Brasileira de Medicina Tropical, Uberaba, v. 44, n. 2, p. 191-193, 2011. https://doi.org/10.1590/S0037-86822011005000022

GURGEL, R. Q.; CARDOSO, G. S.; SILVA, A. M.; SANTOS, L. N.; OLIVEIRA, R. C. V. Creche: ambiente expositor ou protetor nas infestações por parasitas intestinais em Aracaju, SE. Revista da Sociedade Brasileira de Medicina Tropical, Uberaba, v. 38, n. 3, p. 267-269, 2005. https://doi.org/10.1590/S003786822005000300014

LEITE, A. C. R. Ancylostomidae. In: NEVES, D. P.; MELO, A. L.; LINARDI, P. M.; VITOR, R. W. A. Parasitologia Humana. São Paulo: Atheneu 2005, p. 234-242.

LINDSAY, D. S.; DUBEY, J. P.; BLAGBURN, B. L. Biology of Isospora spp from Humans, Nonhuman Primates, and Domestic Animals. Clinical Microbiology Reviews, Washington, v. 10, n. 1, p. 19-34, 1997.

MELO, M. C. B.; KLEM, V. G. Q.; MOTA, J. A. C.; PENNA, F. J. Parasitoses intestinais. Revista Médica de Minas Gerais, Belo Horizonte, v. 14, n. 1, p. 3-12, 2004.

MELO, E. M. Importância do estudo da prevalência de parasitos intestinais de crianças em idade escolar. Revista de Saúde e Biologia, Campo Mourão, v. 5, n. 1, p. 43-47, 2010.

MORRONE, F. B.; CARNEIRO, J. A.; REIS, C.; CARDOZO, C. M.; UBAL, C.; CARLI, G. A. Study of enteroparasites infection frequency and chemotherapeutic agents used in pediatric patients in a community living in Porto Alegre, RS, Brazil. Revista do Instituto de Medicina Tropical de São Paulo, São Paulo, v. 46, n. 2, 77-80, 2004. https://doi.org/10.1590/S0036-46652004000200004

NAVARRO, I. T.; KANO, F. S.; OGAWA, L.; FREIRE, R. L.; VIDOTTO, O. Ocorrência de Cryptosporidium spp. Em cães com diarreia atendidos no Hospital Veterinário da Universidade Estadual de Londrina, PR. Semina, Ciências Agrárias, Londrina, v. 18, n. 1, p. 23-25, 1997. 
OLIVEIRA, C. A. F.; GERMANO, P. M. L. Estudo da ocorrência de enteroparasitas em hortaliças comercializadas na região metropolitana de São Paulo, SP, Brasil, I - Pesquisa de helmintos. Revista de Saúde Pública, São Paulo, v.26, n.4, p.283-289, 1992. https://doi.org/10.1590/S0034-89101992000400011

OLIVEIRA, A. A. Enteroparasitas em populações usuárias de diferentes sistemas de abastecimento de água em Viçosa-MG, 2004, 131f. Dissertação. (Mestrado em Medicina Veterinária), Universidade Federal de Viçosa; Viçosa, 2004.

PFUETZENREITER, M. R.; PIRES, F. D. A. Epidemiologia da teníase/cisticercose por Taenia solium e Taenia saginata. Ciência Rural, Santa Maria, v. 30, n. 3, p. 541-548, 2000. https://doi.org/10.1590/S010384782000000300030

ROCHA, R. S.; SILVA, J. G.; PEIXOTO, S. V.; CALDEIRA, R. L.; FIRMO, J. O. A.; CARVALHO, O. S. Avaliação da esquistossomose e de outras parasitoses intestinais em escolas do município de Bambuí-MG, Brasil. Revista da Sociedade Brasileira de Medicina Tropical, Uberaba, v. 33, n. 5, p. 431-436, 2000. https://doi.org/10.1590/S0037-86822000000500004

SILVA, N. R.; CHAN, M. S.; BUNDY, D. A. P. Morbidity and mortality due to ascariasis: re-estimation and sensivity analysis of global numbers at risk. Tropical Medicine $\boldsymbol{\&}$ International Health, Medford, v. 2, n. 6 , p. 519-528, 1997. https://doi.org/10.1046/j.1365-3156.1997.d01-320.x

SILVA, A. V. M. Ascaris lumbricoides. In: NEVES, D. P.; MELO, A. L.; LINARDI, P. M.; VITOR, R. W. A. Parasitologia Humana. São Paulo: Atheneu 2005, p. 228-233.

SILVA, E. F.; GOMES, M. A. Amebíase: Entamoeba histolytical Entamoeba díspar. In: NEVES, D. P.; MELO, A. L.; LINARDI, P. M.; VITOR, R. W. A. Parasitologia Humana. São Paulo: Atheneu 2005, p. 114124.

WHO - World Health Organization. Report of a Consultation of Experts on Amebiasis. Weekly Epidemiological Report of the World Health Organization 1997; 72:97-99. 